\title{
Studi Kinetika dan Adsorpsi Zat Warna Kation (Metilen Biru) dan Anion (Metil Orange) pada Magnetit Terlapis Asam Humat
}

\section{Adsorption and Kinetic Studies of Cationic (Methylene Blue) and Anionic (Methyl Orange) Dyes onto Magnetite Coated with Humic Acid}

\author{
Kustomo $^{1 *}$, Sri Juari Santosa ${ }^{2}$ \\ ${ }^{1}$ Jurusan Kimia, Fakultas Sains dan Teknologi, Universitas Islam Negeri Walisongo, Semarang, Jawa Tengah 50185 \\ ${ }^{2}$ Jurusan Kimia, Fakultas Matematika dan Ilmu Pengetahuan Alam, Universitas Gadjah Mada, Sekip Utara, Yogyakarta 55281 \\ *Alamatemail: kustomo@walisongo.ac.id
}

\begin{abstract}
Abstrak - Sintesis magnetit terlapis asam humat ( $\mathrm{Fe}_{3} \mathrm{O}_{4}-\mathrm{HA}$ ) telah dilakukan untuk adsorpsi dari dua jenis zat warna, yaitu metilen biru $(M B)$ dan metil orange (MO). Penelitian ini diawali dengan ekstraksi asam humat (HA) yang diperoleh dari hasil isolasi tanah gambut Rawa Pening, Ambarawa, Jawa Tengah dan dilanjutkan dengan sintesis $\mathrm{Fe}_{3} \mathrm{O}_{4}-\mathrm{HA}$ menggunakan metode kopresipitasi dengan agen pengendap $\mathrm{NH}_{4} \mathrm{OH}$ pada campuran garam $\mathrm{FeSO}_{4} \cdot 7 \mathrm{H}_{2} \mathrm{O}$, $\mathrm{FeCl}_{3} \bullet 6 \mathrm{H}_{2} \mathrm{O}$ dan $\mathrm{HA}$ hasil ekstraksi. $\mathrm{Fe}_{3} \mathrm{O}_{4}-\mathrm{HA}$ hasil sintesis kemudian dikarakterisasi dengan spektroskopi FTIR dan difraktogram XRD. Proses adsorpsi dilakukan pada waktu keseimbangan optimum MB dan MO dengan menggunakan kinetika adsorpsi orde satu semu, orde dua semu, dan kinetika Santosa. Hasil penelitian menunjukkan bahwa adsorpsi $M B$ dan $\mathrm{MO}$ oleh $\mathrm{Fe}_{3} \mathrm{O}_{4}-\mathrm{HA}$ mengikuti model kinetika adsorpsi orde dua semu dengan nilai konstanta keseimbangan adsorpsi (k) secara berurutan adalah 107304,348 $\mathrm{L} \mathrm{mol}^{-1}$ untuk $\mathrm{MB}$, dan 80361,011 $\mathrm{L} \mathrm{mol}^{-1}$ untuk MO. Data adsorpsi ini diperoleh pada kondisi pH optimum pada MB dan MO secara berurutan pada pH 7 dan 2, serta tercapai waktu keseimbangan untuk MB dan MO secara berurutan pada 30 dan 15 menit.
\end{abstract}

Kata kunci: $\mathrm{Fe}_{3} \mathrm{O}_{4}-\mathrm{HA}$, adsorpsi, $\mathrm{MB}, \mathrm{MO}$

\begin{abstract}
Synthesis of magnetite coated with humic acid ( $\mathrm{Fe}_{3} \mathrm{O}_{4}-\mathrm{HA}$ ) has been done to adsorp two different dyes, i.e. methylene blue, $M B$ (cationic dye) and methyl orange, $M O$ (anionic dye). First though, this research start with an extraction of humic acid which was obtained from the isolation of peat soil in Rawa Pening, Ambarawa, the Province of Central Java and continued with the synthesis of $\mathrm{Fe}_{3} \mathrm{O}_{4}-\mathrm{HA}$ by coprecipitation method using $\mathrm{NH}_{4} \mathrm{OH}$ as precipitating agent from a mixture of $\mathrm{FeSO}_{4} \cdot 7 \mathrm{H}_{2} \mathrm{O}, \mathrm{FeCl}_{3} \cdot 6 \mathrm{H}_{2} \mathrm{O}$ and extracted $\mathrm{HA}$. The result of synthesis $\mathrm{Fe}_{3} \mathrm{O}_{4}$ - $\mathrm{HA}$ have been characterized by spectroscopy FTIR and difractogram XRD. Dyes adsorption process was thoroughly studied from equilibrium points of $M B$ and $M O$ which was tested for the pseudo-first order, pseudo-second order, and Santosa kinetics. The results of this research showed that adsorption $\mathrm{MB}$ and $\mathrm{MO}$ onto $\mathrm{Fe}_{3} \mathrm{O}_{4}-\mathrm{HA}$ were followed the model of kinetic adsorption pseudo-second with the value of adsorption equilibrium constant $(k)$ is 107,304.348 $\mathrm{L} \mathrm{mol}^{-1}$ for adsorption methylene blue (MB) and $80361.011 \mathrm{~L} \mathrm{~mol}^{-1}$ for adsorption methyl orange (MO). This adsorption data was obtained at the condition of $\mathrm{pH}$ maksimum for adsorption $\mathrm{MB}$ and $\mathrm{MO}$ subsequently at $\mathrm{pH} 7$ and 2, and the equilibrium time for adsorption $M B$ and $M O$ at 30 and 15 minutes, respectively.
\end{abstract}

Keywords: $\mathrm{Fe}_{3} \mathrm{O}_{4}-\mathrm{HA}$, adsorption, $\mathrm{MB}, \mathrm{MO}$

(C) 2019 Jurnal Jejaring Matematika dan Sains. This work is licensed under a CC BY-NC 4.0

Sejarah Artikel

Diterima : 18 Desember 2019

Disetujui : 24 Desember 2019

\section{PENDAHULUAN}

Perkembangan industri yang semakin pesat menimbulkan dampak berupa limbah-limbah industri yang semakin bertambah pula baik volume maupun jenisnya. Industri tekstil merupakan salah satu jenis industri di Indonesia. Zat warna dalam industri tekstil merupakan salah satu bahan baku utama yang memberikan kontribusi besar dalam pencemaran lingkungan, sekitar 10 - 15\% dari zat warna yang sudah digunakan tersebut tidak dapat dipakai ulang dan harus dibuang [1]. Selain itu, zat warna yang telah dibuang sebagai limbah ke lingkungan merupakan pencemar organik yang bersifat non biodegradable terhadap lingkungan [2]. Zat warna tekstil umumnya dibuat dari senyawa azo dan turunannya yang merupakan gugus benzena. Diketahui bahwa gugus benzena sangat sulit didegradasi, kalaupun dimungkinkan dibutuhkan waktu yang lama. Senyawa azo bila terlalu lama berada di 
lingkungan, akan menjadi sumber penyakit karena sifatnya karsinogen dan mutagenik [3].

Kemajuan ilmu pengetahuan dan teknologi terbaru di bidang nanoteknologi telah memberikan andil dalam pembuatan nanopartikel oksida besi yang memiliki luas permukaan besar dan sifat magnetik material yang memudahkan pemisahan zat warna menjadi lebih efisien dalam waktu singkat dengan menggunakan bantuan medan magnet luar [4,5]. Nanopartikel oksida besi telah menjadi perhatian para peneliti saat ini karena prosedur sintesis yang terlibat lebih sederhana dan dengan biaya modal yang rendah dibandingkan dengan tersedia secara komersial karbon aktif [6]. $\mathrm{Fe}_{3} \mathrm{O}_{4}$ merupakan salah satu besi oksida yang memiliki sifat magnetik yang besar dan memiliki warna hitam [7]. $\mathrm{Fe}_{3} \mathrm{O}_{4}$ sebagai salah satu material dengan sifat magnetik yang dimilikinya telah banyak digunakan sebagai media perekam seperti audio dan video tape, kaset perekam dan cairan magnetik (magnetic fluids). Dalam dunia medis, $\mathrm{Fe}_{3} \mathrm{O}_{4}$ banyak digunakan termasuk di antaranya adalah diagnosis medis, sensor, terapi kanker, katalis, microwave radio frequency hypothermia, dan magnetic sensing [8].

Penelitian senyawa $\mathrm{Fe}_{3} \mathrm{O}_{4}$ nanopartikel memang telah dikembangkan sebagai adsorben untuk penghilangan logam berat dan limbah zat warna di dalam lingkungan perairan. Akan tetapi, belum banyak yang mengkaji tentang proses modifikasi pelapisan $\mathrm{Fe}_{3} \mathrm{O}_{4}$ dengan senyawa lain karena $\mathrm{Fe}_{3} \mathrm{O}_{4}$ sangat mudah teroksidasi oleh udara dan juga mudah membentuk agregat di dalam sistem berair [9]. Oleh karena itu, stabilitas $\mathrm{Fe}_{3} \mathrm{O}_{4}$ perlu diatasi dengan modifikasi lapisan permukaan $\mathrm{Fe}_{3} \mathrm{O}_{4}$ dengan bahan pelapis yang sesuai [5,10,11]. Asam humat (HA) yang di ekstraksi dari tanah gambut ini diharapkan selain memiliki kemampuan dalam menstabilkan $\mathrm{Fe}_{3} \mathrm{O}_{4}$ juga memiliki kapasitas adsorpsi yang tinggi terhadap zat warna tersebut [12].

Fokus penelitian ini adalah untuk mempelajari kinetika adsorpsi dari sintesis magnetit terlapisi asam humat $\left(\mathrm{Fe}_{3} \mathrm{O}_{4}-\mathrm{HA}\right)$ pada adsorpsi zat warna azo kation (metilen biru) dan anion (metil orange). Uji karakterisasi dilakukan dengan Spektrofotometer Infra merah (FTIR) dan difraktometer sinar-X (XRD) untuk mengetahui keberhasilan sintesis dan pengujian aplikasinya. Dengan diperolehnya informasi dari hasil penelitian ini, diharapkan akan dapat memberikan manfaat dan dilanjutkan penelitian secara berkesinambungan terkait pengolahan limbah perairan (waste water treatment) menggunakan material magnetit terlapisi asam humat $\left(\mathrm{Fe}_{3} \mathrm{O}_{4}-\mathrm{HA}\right)$.

\section{METODE PENELITIAN}

\section{A. Alat dan Bahan}

Alat yang digunakan dalam penelitian ini adalah stirer and hot plate (Nouva), pengaduk magnet, neraca analitik (Mettler Toledo AL204), sentrifugator (K PLC series), lumpang dan mortal agat, $\mathrm{pH}$-meter elektrik (Hanna Instrument 211), oven (Fischer Scientific model
655F), ayakan tepung, ayakan 100 mesh, magnet eksternal dan shaker (VRN 200), termometer (Yenako), labu ukur, labu takar, pipet ukur (Pyrex), dan instrumen analisis yang digunakan dalam penelitian ini meliputi spektrofotometer inframerah (Shimadzu FTIR Prestige 21), spektrofotomer AAS (Perkin Elmer 3110), spektrofotometer UV-Vis (Optima SP-300), difraktometer sinar-X (XRD Rigaku JICA Multiflex $2 \mathrm{~kW}$ ), serta alat penunjang berupa alat gelas dan plastik laboratorium.

Bahan yang digunakan dalam penelitian ini adalah asam humat (HA) yang diekstraksi dari tanah gambut Rawa Pening, Ambarawa, Jawa Tengah. Larutan $\mathrm{NaOH}, \mathrm{HCl} 37 \%, \quad \mathrm{NH}_{4} \mathrm{OH} 25 \%, \quad \mathrm{FeCl}_{3} .6 \mathrm{H}_{2} \mathrm{O}$, $\mathrm{FeSO}_{4} .7 \mathrm{H}_{2} \mathrm{O}, \mathrm{Ca}\left(\mathrm{CH}_{3} \mathrm{COO}\right)_{2}, \mathrm{NaNO}_{3}, \mathrm{HNO}_{3}$, larutan standar Fe, Hidrat Metilen Biru $(\mathrm{BM}=355,5)$, Hidrat Metil Orange $(\mathrm{BM}=327)$, indikator $\mathrm{pH}$ universal (dibuat oleh E.Merck), aquades (CV. Progo Yogyakarta), $\mathrm{Ba}(\mathrm{OH})_{2}$, larutan buffer $\mathrm{pH} 4$ dan $\mathrm{pH} 7$ (CV. Chemix Pratama, Yogyakarta), kertas Whatman 42 diameter 90mm (E. Merck) dan gas $\mathrm{N}_{2}$ (CV. Perkasa)

\section{B. Prosedur Penelitian}

Ekstraksi asam humat Tanah gambut dikeringkan pada suhu kamar, kemudian dipisahkan dari ranting dan akar. Tanah digerus dan diayak dengan ayakan tepung dilanjutkan dengan ayakan 100 mesh. Seratus gram tanah gambut 100 mesh ditambahkan 1 liter $\mathrm{NaOH}$ 0,1 $\mathbf{M}$ dan diaduk dengan pengaduk magnet selama 30 menit. Campuran didiamkan selama 24 jam pada wadah plastik dan ditutup rapat. Campuran disentrifugasi pada kecepatan 5000 rpm selama 30 menit. Supernatan yang diperoleh diasamkan dengan $\mathrm{HCl} 0,1 \mathrm{M}$ hingga $\mathrm{pH} 1$ dan disentrifugasi kembali pada $5000 \mathrm{rpm}$ selama 30 menit. Endapan yang diperoleh diuapkan pada suhu $60^{\circ} \mathrm{C}$ hingga diperoleh padatan berwarna cokelat. Setelah kering, padatan digerus dengan lumpang dan mortal agat hingga halus lalu dilakukan karakterisasi asam humat dengan FTIR, XRD, dan SEM.

Sintesis magnetit terlapis asam humat ( $\left.\mathrm{Fe}_{3} \mathrm{O}_{4}-\mathrm{HA}\right)$ Sebanyak 2,78 gram $(0,01 \mathrm{~mol}) \mathrm{FeSO}_{4} .7 \mathrm{H}_{2} \mathrm{O}$ yang dilarutkan dalam $100 \mathrm{~mL}$ aquades dicampurkan dengan 5,41 gram $(0,02 \mathrm{~mol}) \mathrm{FeCl}_{3} \cdot 6 \mathrm{H}_{2} \mathrm{O}$ yang telah dilarutkan dalam $100 \mathrm{~mL}$ aquades. Larutan dipanaskan pada $90^{\circ} \mathrm{C}$ sambil diaduk dan dialiri gas $\mathrm{N}_{2}$. Ditambahkan larutan $10 \mathrm{~mL} \mathrm{NH} \mathrm{NH}_{4} \mathrm{OH}(25 \% \mathrm{v} / \mathrm{v})$ dan 1 gram HA secara cepat dan berurutan. Campuran diaduk pada $90^{\circ} \mathrm{C}$ selama 30 menit. Pengadukan dihentikan dan campuran didiamkan pada $90^{\circ} \mathrm{C}$ selama 30 menit. Campuran didinginkan pada suhu kamar, kemudian disaring dan endapan yang diperoleh dicuci dengan $50 \mathrm{~mL}$ aquades sebanyak 3 kali (dengan bantuan medan magnet eksternal). Endapan hasil pencucian dipanaskan menggunakan oven pada suhu $60^{\circ} \mathrm{C}$, kemudian dikarakterisasi dengan FTIR dan $\mathrm{XRD}$ untuk mengetahui keberhasilan dari sintesis $\mathrm{Fe}_{3} \mathrm{O}_{4}-\mathrm{HA}$.

Penentuan kinetika adsorpsi Sebanyak $20 \mathrm{mg} \mathrm{Fe}_{3} \mathrm{O}_{4}$ HA dicampurkan dengan $20 \mathrm{~mL}$ larutan adsorbat zat warna (MB dan MO), masing-masing dengan konsentrasi yang sama $\left(10 \mathrm{mg} \mathrm{L}^{-1}\right)$ pada $\mathrm{pH}$ optimum. 
Campuran kemudian digojog dengan variasi waktu $1 ; 2$; $5 ; 10 ; 15 ; 30 ; 50 ; 100 ; 150 ; 200 ; 250 ;$ dan 300 menit. Campuran disaring dengan menggunakan kertas Whatman 42 (dengan bantuan medan magnet eksternal pada bagian bawah botol). Filtrat yang diperoleh dianalisis dengan spektrofotometer UV-Vis sesuai dengan panjang gelombang maksimal masing-masing.

\section{HASIL DAN PEMBAHASAN}

A. Karakterisasi $\mathrm{HA}, \mathrm{Fe}_{3} \mathrm{O}_{4}$ dan $\mathrm{Fe}_{3} \mathrm{O}_{4}-\mathrm{HA}$ dengan FTIR

Menurut Maity (2007) melaporkan bahwa $\mathrm{Fe}_{3} \mathrm{O}_{4}$ memiliki pita serapan yang lebar dan menyebar pada bilangan gelombang sekitar 590-579 $\mathrm{cm}^{-1}$ yang merupakan vibrasi ulur $\mathrm{Fe}-\mathrm{O}$. Karakterisasi spektroskopi infra merah magnetit terlapis asam humat $\left(\mathrm{Fe}_{3} \mathrm{O}_{4}-\mathrm{HA}\right)$ hasil penelitian ini disajikan pada Gambar 1. Dalam penelitian ini, pita serapan utama terjadi pada bilangan gelombang $586 \mathrm{~cm}^{-1}$ yang menunjukkan vibrasi ulur $\mathrm{Fe}-\mathrm{O}$ magnetit. Perbedaan signifikan dalam spektra IR ini terlihat pada bilangan gelombang 1397 $\mathrm{cm}^{-1}$ untuk vibrasi ulur - $\mathrm{CO}$ dari $\mathrm{Fe}_{3} \mathrm{O}_{4}$ - $\mathrm{HA}$ yang tidak ditemukan pada spektra $\mathrm{Fe}_{3} \mathrm{O}_{4}$, disertai hilangnya puncak serapan pada pada bilangan gelombang $2924 \mathrm{~cm}^{-1}$ yang merupakan vibrasi ulur $-\mathrm{C}-\mathrm{H}$ alifatik, yang menunjukkan pengikatan $\mathrm{HA}$ pada $\mathrm{Fe}_{3} \mathrm{O}_{4}$ dan hilangnya puncak serapan bilangan gelombang $1700 \mathrm{~cm}^{-1}$, yang menunjukan ikatan anion - $\mathrm{COO}^{-}$dengan permukaan $\mathrm{Fe}_{3} \mathrm{O}_{4}$ [13]. Hal ini menunjukan bahwa gugus karboksilat berperan penting dalam ikatan dari HA ke permukaan $\mathrm{Fe}_{3} \mathrm{O}_{4}$. Terlihat pula pada spektra $\mathrm{Fe}_{3} \mathrm{O}_{4}-\mathrm{HA}$ puncak serapan pada bilangan gelombang $3410 \mathrm{~cm}^{-1}$ yang merupakan vibrasi ulur gugus $-\mathrm{OH}$ yang menunjukan adanya ikatan hidrogen pada permukaan $\mathrm{Fe}_{3} \mathrm{O}_{4}$ yang tidak ditemukan pada spektra $\mathrm{Fe}_{3} \mathrm{O}_{4}[14]$.

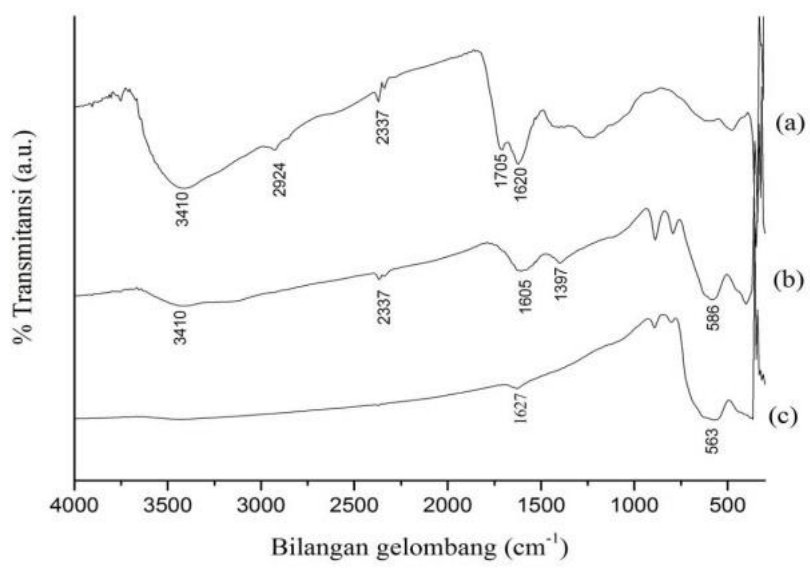

Gambar 1. Spektra IR (a) asam humat, (b) $\mathrm{Fe}_{3} \mathrm{O}_{4}-\mathrm{HA}$ dan (c) $\mathrm{Fe}_{3} \mathrm{O}_{4}$

Analisis spektroskopi IR $\mathrm{Fe}_{3} \mathrm{O}_{4}-\mathrm{HA}$ seperti yang disajikan pada gambar 1 menunjukkan keberhasilan pelapisan $\mathrm{HA}$ pada permukaan $\mathrm{Fe}_{3} \mathrm{O}_{4}$. Di sisi lain, $\mathrm{Fe}_{3} \mathrm{O}_{4}-\mathrm{HA}$ memiliki intensitas serapan pada daerah 3400 dan $1600 \mathrm{~cm}^{-1}$ yang lebih tinggi daripada $\mathrm{Fe}_{3} \mathrm{O}_{4}$, hal ini dikarenakan $\mathrm{Fe}_{3} \mathrm{O}_{4}-\mathrm{HA}$ memiliki sumbangan gugus
-OH yang melimpah dari gugus-gugus karboksilat dan fenolat HA.

\section{B. Karakterisasi $\mathrm{HA}, \mathrm{Fe}_{3} \mathrm{O}_{4}$ dan $\mathrm{Fe}_{3} \mathrm{O}_{4}-\mathrm{HA}$ dengan XRD.}

Karakterisasi dengan difraktometer sinar-X bertujuan untuk mengetahui kristalinitas, puncakpuncak utama dan ukuran dari partikel $\mathrm{HA}, \mathrm{Fe}_{3} \mathrm{O}_{4}$, dan $\mathrm{Fe}_{3} \mathrm{O}_{4}-\mathrm{HA}$ yang telah disintesis. Pada gambar 2 disajikan puncak-puncak karakteristik difraktogram asam humat (HA), magnetit $\left(\mathrm{Fe}_{3} \mathrm{O}_{4}\right)$, dan magnetit terlapis asam humat $\left(\mathrm{Fe}_{3} \mathrm{O}_{4}-\mathrm{HA}\right)$. Pada difaktogram asam humat (HA) tidak ditunjukan dan tidak diketahui nilai intensitas tertentu pada $2 \theta$ manapun pada rentang $0^{\circ}-70^{\circ}$. Hal ini menunjukan asam humat telah murni dan tidak terdapat bahan pengotor atau terdapat bahan pengotor tapi keberadaannya sangat sedikit/kecil sekali sehingga tidak ditunjukan intensitas tertentu.

Pada difaktogram magnetit terlapis asam humat $\left(\mathrm{Fe}_{3} \mathrm{O}_{4}-\mathrm{HA}\right)$ terlihat nilai intensitas yang berada pada daerah $20^{\circ}-70^{\circ}$, yaitu pada $30,09^{\circ} ; 35,42^{\circ} ; 43,05^{\circ}$; $56,94^{\circ}$ dan $62,51^{\circ}$. Puncak-puncak karakteristik tersebut sesuai dengan Indeks Miller pada JCPDS nomor 00019-0629, yaitu memiliki nilai (hkl): (220), (311), (400), (511) dan (440). Pada 53,23 ${ }^{\circ}$ terdapat karakter gutit $(\alpha-\mathrm{FeOOH})$ yang merupakan pengotor umum pada $\mathrm{Fe}_{3} \mathrm{O}_{4}$ yang disintesis dengan menggunakan metode kopresipitasi.

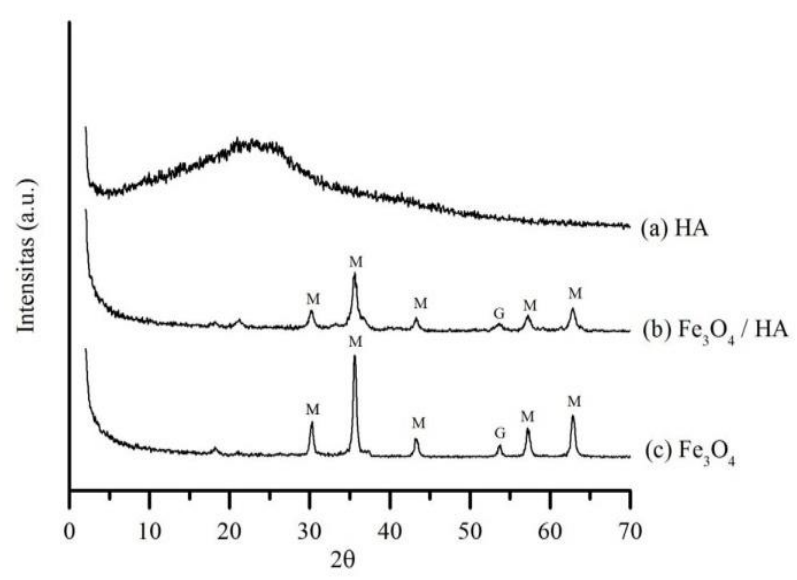

Gambar 2. Difraktogram (a) $\mathrm{HA}$; (b) $\mathrm{Fe}_{3} \mathrm{O}_{4}-\mathrm{HA}$; dan (c) $\mathrm{Fe}_{3} \mathrm{O}_{4}$

(Keterangan: $\mathrm{M}=$ Magnetit, $\mathrm{G}=\mathrm{Gutit}$ )

Berdasarkan difraktogram dapat diketahui bahwa $\mathrm{Fe}_{3} \mathrm{O}_{4}-\mathrm{HA}$ memiliki puncak-puncak yang sama dengan $\mathrm{Fe}_{3} \mathrm{O}_{4}$, tetapi mengalami penurunan intensitas. Hal tersebut menunjukkan bahwa magnetit pada $\mathrm{Fe}_{3} \mathrm{O}_{4}-\mathrm{HA}$ memiliki struktur yang sama dengan $\mathrm{Fe}_{3} \mathrm{O}_{4}$, tetapi mengalami penurunan kristalinitas. Penurunan kristalinitas magnetit pada $\mathrm{Fe}_{3} \mathrm{O}_{4}-\mathrm{HA}$ mengindikasikan bahwa permukaan $\mathrm{Fe}_{3} \mathrm{O}_{4}$ berinteraksi dengan $\mathrm{HA}$, sehingga dapat disimpulkan bahwa imobilisasi HA oleh $\mathrm{Fe}_{3} \mathrm{O}_{4}$ telah berhasil dilakukan. Penurunan kristalinitas ini dibuktikan dengan perhitungan $\%$ kristalinitas pada $\mathrm{Fe}_{3} \mathrm{O}_{4}$ dan $\mathrm{Fe}_{3} \mathrm{O}_{4}-\mathrm{HA}$. 


\section{Kinetika Adsorpsi}

Kinetika adsorpsi zat warna kation (MB) dan anion (MO) diperoleh dengan menginteraksikan $\mathrm{Fe}_{3} \mathrm{O}_{4}$ $\mathrm{HA}$ dan masing-masing zat warna (MB dan MO) pada berbagai variasi waktu hingga diperoleh kesetimbangan adsorpsi. Waktu interaksi yang diperlukan untuk mencapai kesetimbangan adsorpsi merupakan ukuran dari laju reaksi. Semakin cepat waktu yang diperoleh untuk mencapai kesetimbangan, maka laju reaksi adsorpsi semakin besar. Kesetimbangan adsorpsi diperoleh ketika penambahan waktu interaksi tidak memberikan penambahan jumlah ion yang teradsorp pada $\mathrm{Fe}_{3} \mathrm{O}_{4}-\mathrm{HA}$ secara signifikan.

Hasil pengamatan pengaruh waktu interaksi antara zat warna (MO/MB) dengan $\mathrm{Fe}_{3} \mathrm{O}_{4}-\mathrm{HA}$ disajikan pada gambar 3. Berdasarkan gambar 3 diketahui bahwa jumlah zat warna (MO/MB) yang teradsorp pada $\mathrm{Fe}_{3} \mathrm{O}_{4}-\mathrm{HA}$ meningkat dengan bertambahnya waktu interaksi sampai terjadi kesetimbangan. Pada menitmenit awal adsorpsi zat warna (MO/MB) terjadi secara cepat, kemudian semakin lambat hingga diperoleh kesetimbangan pada menit ke-30 untuk adsorpsi MB dan pada menit ke-15 untuk adsorpsi MO. Kesetimbangan yang terjadi dibuktikan dengan tidak bertambahnya jumlah MB/MO yang teradsorp pada $\mathrm{Fe}_{3} \mathrm{O}_{4}-\mathrm{HA}$ secara signifikan. Pada menit awal sampai menit ke 2, adsorpsi berlangsung cepat karena situs aktif $\mathrm{Fe}_{3} \mathrm{O}_{4}-\mathrm{HA}$ belum banyak berinteraksi dengan $\mathrm{MB} / \mathrm{MO}$, sehingga memudahkan MB/MO dalam mengisi situs aktif tersebut. Sebaliknya, setelah menit ke 2 penambahan $\mathrm{MB} / \mathrm{MO}$ semakin lambat. Hal ini dikarenakan keberadaan situs aktif yang digunakan untuk berinteraksi semakin sedikit, sehingga dibutuhkan waktu yang relatif lebih lama bagi situs aktif yang tersisa untuk berinteraksi dengan MB/MO.

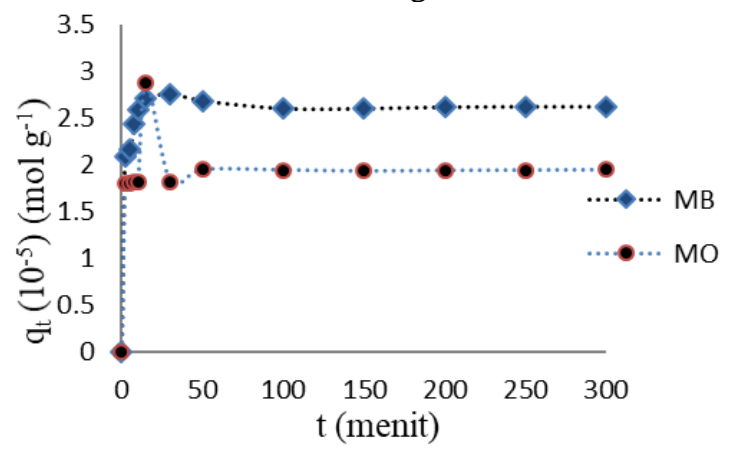

Gambar 3. Pengaruh waktu kontak adsorpsi MB dan $\mathrm{MO}$ oleh $\mathrm{Fe}_{3} \mathrm{O}_{4}$-HA
Konstanta laju reaksi merupakan salah satu parameter penting dalam mempelajari kinetika adsorpsi. Dalam penelitian ini, penentuan konstanta laju adsorpsi $\mathrm{MB} / \mathrm{MO}$ pada $\mathrm{Fe}_{3} \mathrm{O}_{4}-\mathrm{HA}$ ditentukan menggunakan model kinetika orde satu semu Lagergren [15], orde dua semu [16], dan persamaan kinetika adsorpsi Santosa [17].

Persamaan kinetika orde satu semu Lagergren dituliskan sebagai berikut:

$$
\log \left(\mathrm{q}_{\mathrm{e}}-\mathrm{q}_{\mathrm{t}}\right)=\log \mathrm{q}_{\mathrm{e}}-\mathrm{k}_{1} \mathrm{t}
$$

dimana $\mathrm{q}_{\mathrm{t}}, \mathrm{q}_{\mathrm{e}}$, dan $\mathrm{k}_{1}$ masing-masing merupakan jumlah adsorbat yang teradsorpsi pada waktu $t$, jumlah adsorbat yang teradsorp pada saat kesetimbangan (mol $\mathrm{g}^{-1}$ ) dan konstanta laju adsorpsi $\left(\right.$ menit $\left.^{-1}\right)$. Model kinetika orde semu 1 dilakukan dengan membuat kurva linier antara $\log \left(\mathrm{q}_{\mathrm{e}}-\mathrm{q}_{\mathrm{t}}\right)$ versus $\mathrm{t}$, dengan slope $-k$ dan intersep $\log q_{e}$ untuk menghitung jumlah adsorbat yang teradsorpsi per satuan massa adsorben pada saat kesetimbangan.

Ho (2006) mengemukakan model kinetika adsorpsi orde dua semu yang didasarkan terhadap kapasitas serapan pada fase padatan. Persamaan Ho dinyatakan dengan persamaan:

$$
\frac{t}{q_{t}}=\frac{1}{k_{2} q_{e}^{2}}+\frac{1}{q_{e}} t
$$

Model kinetika orde semu dua dilakukan dengan membuat kurva $\frac{t}{q t}$ versus $t$, dengan slope $\frac{1}{q_{e}}$ dan intersep $\frac{1}{\mathrm{kq}_{\mathrm{e}}^{\mathrm{n}}}$. Dengan dibuat grafik antara $\frac{t}{\mathrm{q} t}$ versus $\mathrm{t}$, maka diperoleh harga qe (terhitung) dan $\mathrm{k} 2$, dimana qe merupakan jumlah adsorbat yang terserap pada kesetimbangan $\left(\mathrm{mol} \mathrm{g}^{-1}\right), q_{t}$ merupakan jumlah adsorbat yang terserap pada waktu $t\left(\mathrm{~mol} \mathrm{~g}^{-1}\right)$ dan $k_{2}$ merupakan konstanta laju adsorpsi $\left(\mathrm{g} \mathrm{mol}^{-1}\right.$ menit $\left.^{-1}\right)$.

Santosa (2014) membuat model kinetika dengan persamaan:

$$
\frac{1}{C_{A e}} \ln \frac{C_{A}\left(C_{A o}-C_{A e}\right)}{C_{A o}\left(C_{A}-C_{A e}\right)}=k_{s} t
$$

di mana $C_{A o}\left(\mathrm{~mol} \mathrm{~L}^{-1}\right), C_{A}\left(\mathrm{~mol} \mathrm{~L}^{-1}\right), C_{A e}\left(\mathrm{~mol} \mathrm{~L}^{-1}\right)$ dan $k_{s}\left(\mathrm{~L} \mathrm{~mol}^{-1}\right.$ menit $\left.^{-1}\right)$ masing-masing adalah konsentrasi awal adsorbat, konsentrasi akhir adsorbat, konsentrasi adsorbat pada saat kesetimbangan dan konstanta laju adsorpsi Santosa. Kemudian dibuat grafik antara $\frac{1}{C_{A e}} \ln \frac{C_{A}\left(C_{A o}-C_{A e}\right)}{C_{A o}\left(C_{A}-C_{A e}\right)}$ vs $t$, sehingga diperoleh slope $k_{s}$. Perbandingan model kinetika adsorpsi MB/MO pada $\mathrm{Fe}_{3} \mathrm{O}_{4}-\mathrm{HA}$ secara berurutan disajikan pada Tabel 1 .

Tabel 1. Hasil perhitungan kinetika adsorpsi $\mathrm{MB} / \mathrm{MO}$ pada $\mathrm{Fe}_{3} \mathrm{O}_{4}-\mathrm{HA}$

\begin{tabular}{llll}
\hline \multicolumn{1}{c}{ Model kinetika } & Parameter & MB & MO \\
\hline Orde satu semu & $\mathrm{r}^{2}$ & 0,9559 & 0,9441 \\
& $\mathrm{q}_{\mathrm{e}}\left(\mathrm{mol} \mathrm{gram}^{-1}\right)$ & $1,3240 \times 10^{-5}$ & $0,3974 \times 10^{-5}$ \\
\multirow{2}{*}{ Orde dua semu } & $\mathrm{k}_{1}\left(\mathrm{menit}^{-1}\right)$ & 0,20542 & 0,01935 \\
& $\mathrm{r}^{2}$ & 0,9999 & 0,9996 \\
\multirow{3}{*}{ Santosa } & $\mathrm{q}_{\mathrm{e}}\left(\mathrm{mol} \mathrm{gram}^{-1}\right)$ & $2,623 \times 10^{-5}$ & $0,903 \times 10^{-5}$ \\
& $\mathrm{k}_{2}\left(\mathrm{~g} \mathrm{~mol}^{-1} \mathrm{menit}^{-1}\right)$ & $800.669,128$ & $69.253,907$ \\
& $\mathrm{r}^{2}$ & 0,8984 & 0,9676 \\
& $\mathrm{k}_{\mathrm{s}}\left(\mathrm{mol}^{-1}\right.$ menit $\left.^{-1}\right)$ & $51.611,00$ & 870,89 \\
\hline
\end{tabular}


Berdasarkan Tabel 1 dapat diketahui bahwa model kinetika orde dua semu memberikan faktor korelasi (r) yang lebih baik dibanding model kinetika orde satu semu dan Santosa. Oleh karena itu, dapat dikatakan bahwa proses adsorpsi $\mathrm{MB}$ dan $\mathrm{MO}$ pada $\mathrm{Fe}_{3} \mathrm{O}_{4}-\mathrm{HA}$ mengikuti model kinetika orde dua semu, dengan konstanta laju adsorpsi MB sebesar 800.669,128 $\mathrm{g} \mathrm{mol}^{-1}$ menit $^{-1}$, sedangkan konstanta laju adsorpsi MO sebesar $69.253,907 \mathrm{~g} \mathrm{~mol}^{-1}$ menit $^{-1}$.

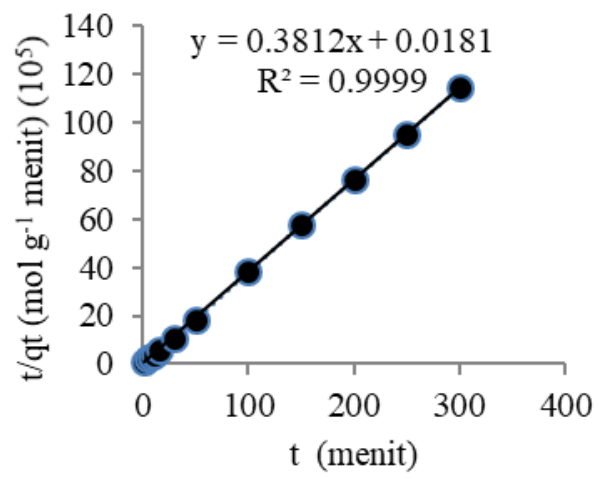

Gambar 4. Model kinetika adsorpsi orde dua semu untuk adsorpsi $\mathrm{MB}$ pada $\mathrm{Fe}_{3} \mathrm{O}_{4}-\mathrm{HA}$

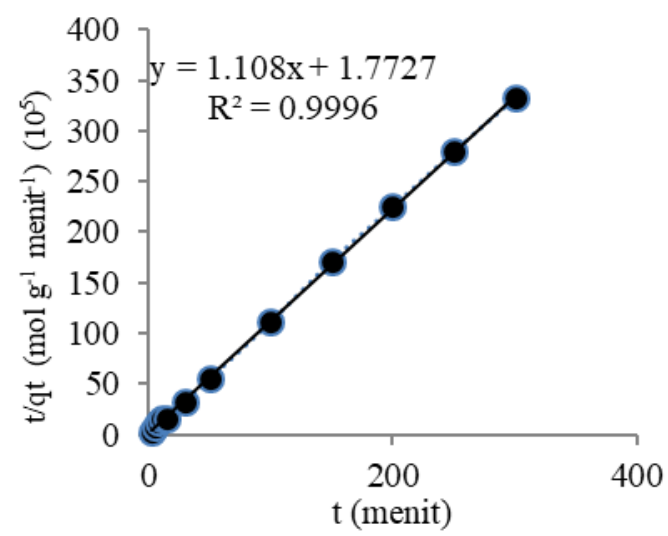

Gambar 5. Model kinetika adsorpsi orde dua semu untuk adsorpsi $\mathrm{MO}$ pada $\mathrm{Fe}_{3} \mathrm{O}_{4}-\mathrm{HA}$

\section{SIMPULAN}

Sintesis $\mathrm{Fe}_{3} \mathrm{O}_{4}-\mathrm{HA}$ dapat dilakukan pada kondisi basa dengan metode kopresipitasi menggunakan campuran garam besi $\mathrm{FeSO}_{4}{ }^{\circ} 7 \mathrm{H}_{2} \mathrm{O}$ dan $\mathrm{FeCl}_{3}{ }^{\circ} 6 \mathrm{H}_{2} \mathrm{O}$ dengan perbandingan 1:2 dan ekstraksi HA pada suhu

$60^{\circ} \mathrm{C}$. Pada uji kinetika adsorpsi zat warna $\mathrm{MB}$ dan $\mathrm{MO}$ pada $\mathrm{Fe}_{3} \mathrm{O}_{4}-\mathrm{HA}$ berlangsung kondisi optimal oleh $\mathrm{Fe}_{3} \mathrm{O}_{4}-$ HA pada waktu kontak keseimbangan MB dan MO secara berurutan yaitu 30 dan 15 menit dengan mengikuti kinetika adsorpsi orde dua semu.

\section{REFERENSI}

[1] Selvam, P., Dapurkar, S.E., Badamali, S.K., Murugasan, M., and Kuwano, H., 2003, Coexistence of Paramagnetic and Supraparamagnetic Fe(III) in Mesoporous MCM-41 Silicates, Catal.Today., 69, 68-74

[2] Wihasti, Eka, P., 2015, Pembuatan nanofiber paduan kitosan-pektin-polivinil alkohol (PVA) dengan electrospining sebagai adsorben biru metilen, Tesis, Jurusan Kimia FMIPA UGM.

[3] Inbaraj, S.B., and Chen, B.H., 2011, Dye adsorption characteristic of magnetite nanoparticle coated with a biopolymer poly (y-glutamic acid), J. Bioresource Tech., 102 (2011) 8868-8876

[4] Afkhami, A., Tehrani, M.S., Bagheri, H., 2010, Modified maghemite nanoparticles as an efficient adsorbent for removing some cationic dyes from aqueous solution, J.Desalination, 263, 240-248.

[5] Afkhami, A., Moosavi, R., Madrakian, T., 2010, Preconcentration and spectrophotometric determination of low concentrations of malachite green and leucomalachite green in water samples by high performance solid-phase extraction using maghemite nanoparticles. J.Desalination, $82,785-789$.

[6] Weng, C.H., Lin, Y.T., Yeh, C.L., Sharma, Y.C., 2010. Magnetic $\mathrm{Fe}_{3} \mathrm{O}_{4}$ nanoparticles for adsorptive removal of acid dye (new coccine) from aqueous solutions. Water Sci. Technol. 62, 844-851.

[7] Cornell, R.M. and Schwertmann, U., 2003, Iron oxide in the laboratory, $\mathrm{VCH}$, New York.

[8] Ghandoor, H. El., Zidan, H.M., Khalil, M.M.H. dan Ismail, I.M., 2012, Synthesis and Some Physical Properties of Magnetite $\left(\mathrm{Fe}_{3} \mathrm{O}_{4}\right)$ Nanoparticles, Int. J. Electrochem. Sci., 7 (2012) 5734.

[9] Maity, D. dan D.C. Agrawal, Synthesis of Iron Oxide Nanoparticles Under Oxidizing Environment and Their Stabilization in Aqueous and Non aqueous Media, 2007, J. Magn. Mater., 308, 46-55.

[10] Mak, S.Y., Chen, D.H., 2004. Fast adsorption of methylene blue on polyacrylic acidbound iron oxide magnetic nanoparticles. Dyes Pigm. 61, 93-98.

[11] Gupta V., Ali I., Saini, V.K., Gerven, T.V., Bruggen B.V., dan Vandecasteele C., 2005, Removal of dyes form Wastewater using Bottom ash, Ind. Eng. Chem. Res. 44, 3655-3664

[12] Peng, L., Qin, P.F., Lei, M., Zeng, Q., Song, H.J., Yang, J., Shao, J.H., Liao, B.H. dan Gu, J.D, 2012, Modifying $\mathrm{Fe}_{3} \mathrm{O}_{4}$ Nanoparticles with Humic Acid for Removal of Rhodamine B in Water, J. Hazard. Mater, 2012, 209-210, 193-198.

[13] Carlos, L., Einschlag, F.S.G., González, M.C. dan Mártire, D.O., 2013, Application of Magnetite Nanoparticles for Heavy Metal Removal from Wastewater, InTech., http://dx.doi.org/10.5772/54608. [17] Ho, Y-S., 2006, Review of Second-Order Models for Adsorption Systems, J. Hazard. Mater., B136, 681-689. 
[14] Petcharoen, K. and Sirivat, A., 2012, Synthesis and Characterization of Magnetite Nanoparticles via the Chemical Co-precipitation Method, Mater. Sci. Eng., B 177,421-427.

[15] Zhang, Xiang, Panyue, Z., Zhen, Wu, Ling, Z., Guangming, Z., 2013, Asorption of Methylene Blue onto humic acid-coated $\mathrm{Fe}_{3} \mathrm{O}_{4}$ nanoparticles, J.of Colloids and Surfaces A: Physicochemical and Engineering Aspects, 435 (2013) 85-90.

[16] Ho, Y-S., 2006, Review of Second-Order Models for Adsorption Systems, J. Hazard. Mater., B136, 681-689.

[17] Santosa, S.J., 2014, Sorption Kinetics of Cd(II) Species on Humic Acid-based Sorbent, CLEAN: Soil, Air, Water. 